International Journal of Development, Vol.9, No.(1) (2020): 23-28

ISSN: 2314-5536

www. ijd.journals.ekb.eg

e-ISSN: 2314-5544 (Online)

e-mail: fas_ijd@yahoo.om

\title{
Estimating the value of the dietary elements of tilapia fish in Ain Tawergha water, Libya
}

\author{
Saleh M Beki \\ Department of Food Sciences - Faculty of Agriculture - Bani Walid University - Libya
}

\begin{abstract}
This study was conducted to find out the nutritional value of tilapia fish found in Ain Tawergha water. As well as to assess the suitability of Ain Tawergha water for growth and development of Tilapia fish. Samples of tilapia fish were caught directly from the Tawerghan basins by fishing nets, and water samples were taken from the same fishing site for analysis. The results obtained from the water samples indicated that the quantities of calcium, magnesium, sodium, and potassium were 292, 147, 494 (and $33 \mathrm{mg} / \mathrm{l}$ ), respectively, while the amount of chlorine was $915 \mathrm{mg} / \mathrm{l}$, and the water $\mathrm{pH}$ was 7.4 and the total dissolved salts were $2940 \mathrm{mg} / 1$. The water was good in transparency and clean without turbidity.

The results also showed that the amount of protein, carbohydrates and fats in fish muscle were $22.086,0$ and $1.87 \mathrm{~g}$, respectively. The minerals in muscles, calcium, iron and sodium were 12, 0.54, $56 \mathrm{mg}$, respectively. The cholesterol $\mathrm{n}$ muscles was $50 \mathrm{mg}$. It was also found that tilapia was rich in important fatty acids for the body (omega-3, which was $0.14 \mathrm{mg}$ ).
\end{abstract}

Keyword : Tilapia fish, Ain Tawergha water, Food elements.

\section{INTRODUCTION}

The marine life of seas, lakes and rivers is a source of food for many people and an important resource to support the national economy and is considered an important source for building the human body because it contains the protein necessary for its health and safety) ${ }^{(\mathbf{1})}$. Among the most important ones is tilapia, whose protein content is estimated at more than $22.50 \%$, and is characterized by ease of digestion and metabolism compared to other meats ${ }^{(2)}$. Tilapia ranks third among the most consumed types of fish in the world, coming directly after carp and salmon, and the demand for tilapia has increased significantly ${ }^{(3)}$. Tilapia fish includes about 100 species that are spread naturally in Africa and Central America until Mexico and the northern part of South America and India. Africa is the natural habitat of the group of tilapia fish, and it was noticed that some naturally occurring tilapia appeared in the Middle East region up to Syria in the north, with some species in Lake of Tiberias ${ }^{(4)}$. Tilapia fish were brought to Ain Tawergha water in Libyan for more than (50 years) ${ }^{(\mathbf{5})}$.

Tilapia is a herbivorous, vegetarian fish whose main food is algae and plant bacteria that live in fresh water and it is characterized by fast growth and its high capacity for endurance, and it lives in fresh water ${ }^{(\mathbf{6})}$ and in hot regions and it dies if the water temperature drops below $10{ }^{\circ} \mathrm{C}$. It is highly tolerant of lack of dissolved oxygen in the water and increased salinity, as these fish have reproductive and behavioral characteristics that differ from the rest of the fish The length of an adult tilapia fish ranges from $6-28 \mathrm{~cm}$, and the maximum recorded weight of a fish of this type is more than $4 \mathrm{~kg}$ and becomes sexually mature at age of few months ${ }^{(7)}$.

This study aims to identify the value of nutrients (protein, carbohydrates and fats) and mineral elements, fatty and amino acids in addition to vitamins in muscles of tilapia grown in Ain Tawergha water, Libya. Also, to investigate the suitability of water there for the development of this fish species. 


\section{MATERIALS AND METHODS}

Samples of tilapia fish were caught from Ain Tawergha water, Libya, in the morning period during July 2019 were placed in plastic bags in a cooler and transferred directly and taken to the laboratory for analysis. Samples of water were also collected in sterile glass test bottles and placed in a sample folder and transferred to the central laboratory of the Ministry of Agriculture to conduct chemical and physical analyzes to determine its suitability for fish growth.

\section{Chemical analyzes:}

Three replicates of the sample were extracted from each fish using the Bligh and Dyer method (1959. Bligh and Dyer) which he used in extracting the fats ${ }^{\mathbf{8 , 9 , 1 0})}$ where 50 grams of the fish sample were mixed with a mixture of organic solvents and by 1-2 the sample was homogenized with a mixture of solvents using a mixer. For a period of 3 minutes, total cholesterol was determined for its color according to the method used by Richmond (1973) ${ }^{(11)}$. The value of the remaining nutrients was also estimated using routine analyzes recognized in foods. Water samples were taken from Ain Tawergha basin, and chemical and physical analyzes were carried out in the central laboratory of the Ministry of Agriculture

\section{RESULTS AND DISCUSSION}

There is a tremendous potential in exploiting the water of Ain Tawergha for the purpose of producing large fish, as the amount of water flowing from the springs is $2 \mathrm{~m} 3 /$ second, which is sufficient to produce more than 5000 tons of fish using the intensive breeding system using ponds or floating cages or both of them ${ }^{(5)}$.

It was clear from the results of the water analyzes (Tables 1,2) that it is suitable for breeding of tilapia fish, whether from a chemical or natural point of view. This is in agreement with previous studies conducted on tilapia ${ }^{(1,7)}$.

Table 1. Average minerals value of samples of water from Ain Tawrgha, Libya.

\begin{tabular}{|l|l|c|}
\hline No. & Mineral & Value / mg/100ml \\
\hline 1 & Calcium & 292 \\
\hline 2 & Magnesium & 147 \\
\hline 3 & Sodium & 494 \\
\hline 4 & Potassium & 33 \\
\hline 5 & Chlorine & 915 \\
\hline 6 & Acidity & 7.4 \\
\hline 7 & Total dissolved salts & 2940 \\
\hline
\end{tabular}

Tab. 2 : The Physical parameters of samples of water from Ain Tawrgha, Libya.

\begin{tabular}{|l|l|l|}
\hline No. & Physical parameter & Value \\
\hline 1 & Color & transparent \\
\hline 2 & Taste & Good \\
\hline 3 & Odor & Odorless \\
\hline 4 & Temperature & $28^{\circ} \mathrm{C}$ \\
\hline
\end{tabular}


The total nutritional percent of protein, carbohydrates, fats of tilapia fish muscles from Ain Tawrgha, Libya was good (Table 3) when it was compared to what the individual needs in the daily dietary components of human. The percentage of protein for tilapia fish muscles was $22.8 \%$ which is in accordance with the results of ${ }^{(6)}$.

The amount of fat in the samples of tilapia fish muscles under investigation was $(1.87 \%$ $\mathrm{g} / 100 \mathrm{~g}$ muscle) which is rich in omega-3 fatty acids $(0.14 \mathrm{~g} / 100 \mathrm{~g}$ of muscle) (Table 4$)$ and this was in agreement with ${ }^{(1,7)}$.

Table (5) shows that the amount of carbohydrates for tilapia fish in Ain Tawergha during this study was zero, so there was no record for sugars in tilapia fish muscle. This result was consistent with ${ }^{(\mathbf{1 , 6})}$.

Analysis of some of the most important vitamins present in tilapia fish muscles indicated their presence in suitable amounts that are necessary for human (Table 6). This is consistent with the study conducted by ${ }^{(3,6)}$.

Table (7) shows the proportion of the investigated mineral elements in tilapia fish muscles is sufficient for human body health. This mineral content is consistent with the result of the study carried out by ${ }^{(3,6)}$.

Table (8) indicates the average quantity of amino acids for tilapia muscles during the study and gave an good indication which in consistent with ${ }^{(\mathbf{6})}$. The total caloric value obtained in the present study for tilapia fish muscles from Ain Tawergha (Table 9) is considered good for meeting the individual's need of daily calories needed by the body ${ }^{(\mathbf{1 2})}$.

Table 3. The food value for tilapia fish muscles from Ain Tawrgha, Libya.

\begin{tabular}{|l|l|l|}
\hline No. & Muscle components & Average value $(\mathrm{g})$ \\
\hline 1 & Fats & 1.87 \\
\hline 2 & Carbohydrate & 0 \\
\hline 3 & protein & 22.086 \\
\hline 4 & cholestrol & $50 \mathrm{mg}$ \\
\hline
\end{tabular}

Table 4. The average quantity of saturated and unsaturated fatty acids in tilapia fish muscles from Ain Tawrgha, Libya.

\begin{tabular}{|l|l|l|}
\hline No. & Fatty acid & $\begin{array}{l}\text { Quantity average (gm/100/gm } \\
\text { of the sample weight }\end{array}$ \\
\hline 1 & Saturated fatty acid & $0.76 \mathrm{gm}$ \\
\hline 2 & Unsaturated fatty acid & $0.65 \mathrm{gm}$ \\
\hline 3 & Polyunsaturated fatty acid & $0.46 \mathrm{gm}$ \\
\hline 4 & Total fat & $1.87 \mathrm{gm}$ \\
\hline 5 & Omega-3 & $0.14 \mathrm{gm}$ \\
\hline
\end{tabular}


Table 5. The average quantity of Carbohydrates, fibers and total sugar in tilapia fish muscles from Ain Tawrgha, Libya.

\begin{tabular}{|l|l|l|}
\hline No. & Item & Average Quantity $(\mathrm{g})$ \\
\hline & Carbohydrates & $0 \mathrm{~g}$ \\
\hline & Fiber & $0 \mathrm{~g}$ \\
\hline & Total sugars & $0 \mathrm{~g}$ \\
\hline & starch & $0 \mathrm{~g}$ \\
\hline & cane sugar & $0 \mathrm{~g}$ \\
\hline & fructose & $0 \mathrm{~g}$ \\
\hline & Lactose & $0 \mathrm{~g}$ \\
\hline & Barley sugar & $0 \mathrm{~g}$ \\
\hline & Galactose & $0 \mathrm{~g}$ \\
\hline
\end{tabular}

Table 6. The average quantity of vitamins in tilapia fish muscles from Ain Tawrgha, Libya.

\begin{tabular}{|l|l|l|}
\hline No. & vitamin & Average Quantity \\
\hline 1 & Vit. C & $0 \mathrm{mg}$ \\
\hline 2 & Vit. B6 & $0.16 \mu \mathrm{g}$ \\
\hline 3 & Vit. B12 & $1.58 \mu \mathrm{g}$ \\
\hline 4 & Vit. A. & $0 \mathrm{IU}$ \\
\hline 5 & Vit. E & 0.4 \\
\hline 6 & Vit. D & $124 \mathrm{IU}$ \\
\hline 7 & Vit. K & $1.4 \mu \mathrm{g}$ \\
\hline 8 & Vit. A & $0 \mathrm{mg}$ \\
\hline 9 & Vit. B1 & $0.04 \mathrm{mg}$ \\
\hline 10 & Vit. B2 & $06 \mathrm{mg}$ \\
\hline 11 & Vit. B3 & $3.9 \mathrm{mg}$ \\
\hline 12 & Pantothenic acid Vit. B5 & $0.49 \mathrm{mg}$ \\
\hline
\end{tabular}

Table 7. The average quantity of minerals in tilapia fish muscles from Ain Tawrgha, Libya.

\begin{tabular}{|l|l|l|}
\hline No. & Element & Average Quantity (g) \\
\hline 1 & Calcium & 10 \\
\hline 2 & iron & 0.56 \\
\hline 3 & Magnesium & $0.27 \mathrm{mg}$ \\
\hline 4 & Phosphorous & 170 \\
\hline 5 & Potassium & 302 \\
\hline 6 & Sodium & 52 \\
\hline 7 & Zinc & 0.33 \\
\hline 8 & Copper & 0.08 \\
\hline 9 & Manganese & 0.04 \\
\hline 10 & Selenium & 41.8 \\
\hline 11 & Fluoride & 0 \\
\hline
\end{tabular}


Tab. 8. The proportion of Basic amino acids in muscles of tilapia fish from Ain Tawergha water, Libya.

\begin{tabular}{|l|l|l|}
\hline No. & Basic amino acids & Quantity average \\
\hline 1 & Tryptophan & $0.21 \mathrm{mg}$ \\
\hline 2 & Threonine & $0.95 \mathrm{mg}$ \\
\hline 3 & Leucine & $1.6 \mathrm{mg}$ \\
\hline 4 & Lysine & $1.81 \mathrm{mg}$ \\
\hline 5 & Methionine & $0.59 \mathrm{mg}$ \\
\hline 6 & Vinyl moan & $0.81 \mathrm{mg}$ \\
\hline 7 & Methionine & $0.59 \mathrm{mg}$ \\
\hline 8 & Cysteine & $0.22 \mathrm{mg}$ \\
\hline 9 & Vinyl moan & $0.81 \mathrm{mg}$ \\
\hline 10 & L-arginine & $1.28 \mathrm{mg}$ \\
\hline
\end{tabular}

Tab. 9 . Calories in components of muscles of tilapia fish from Ain Tawergha water, Libya.

\begin{tabular}{|l|l|l|}
\hline No. & Component & Calories value (Cal) \\
\hline 1 & fat & 15.3 \\
\hline 2 & carbohydrates & 0 \\
\hline 3 & protein & 80.32 \\
\hline \multicolumn{2}{l}{ Total calories } & 95.62 \\
\hline
\end{tabular}

\section{Conclusion and recommendations}

It is evident from the results obtained that the possibility of cultivating tilapia fish in the Tawergha ponds is very available according to the environmental and analytical conditions of the eye water, and that the temperature and the percentage of salts are suitable for carrying out this project, especially since the results of the tilapia fish analyzes gave good nutritional value, and rich in the nutrients necessary for the body of vitamins, minerals and amino acids And a large amount of protein, fats and omega-3 fatty acids. We recommend intensifying fish farming for tilapia in Tawergha because of the positive results it showed as a body lunch, with scientific studies on growth rates and determination of the amount of food naturally available in Tawergha from phytoplankton and animal.

\section{REFERENCES}

1- Ahmed A.A. and Bin Khayal, F.A. (1997). Unsaturated fatty acids and their relationship to high plasma lipid content and clotting. Arab Development Institute, Beirut, Lebanon, p. 23 29 (in Arabic).

2- 2- Bandarra, N.M.; Batista. I.; Nunes, M.L.; Empis, J.M. and Christie, W.W. (1997). Seasonal changes in lipid compstion of sardine (Sardine pilchardus). J. Food Sci., 62 (1): 4042.

3- Nasser S.A.E. (2015). An Economic Study of Fish Production in Egypt. Assiut J. Agric. Sci., 46(6): 86-103. (in Arabic)

4- Bandarra, N.M.; Batista, I.; Bunes, M.L and Empis, J.M. (2001). Seaonal variation in the chemical composition of horse mackerel (Trachurus tachurus). Eur. Food Res.Technol., 212 (5): 535-539. 
Saleh M Beki

5- Herke, H. and Becky, P.M. (2013). The environmental importance of the Libyan Ain Tawergha. Int. J. Develop., 2(1): 101-106. (in Arabic)

6- Al-Juhaimi A.A. (2016). A study on Libyan talapia fish in Wadi Kaam waters. Fac. Sci. AlMarqab Univ. J., 1. (in Arabic)

7- Shakhtour, F.; Hassan, T.M.; Al Mallah, M.A. and Ahmed A.A. (2015). Monthly changes in the composition of kohl fish fat captured from Libyan beaches. Libyan J. Agric. Sci., 20 (2): 29-41. (in Arabic)

8- Shakhtour, F.; Hassan, T.M.; Ahmed, A., El-Malah, M. A. (2006). Monthly changes in the composition of sardine fat caught from Libyan beaches., Libyan J. Mar. Sci.,11: 5-24 (in arabic)

9- Fish Farms Center (2007). Bulletin about the Tilapia Cultivation Program - Ministry of Agric. in Saudi Arabia (in Arabic)

10- Al-Barwani, M.; Prabhakar, A.; Dorr, J. and AL-Mandhery, M. (1989). Studies on the biology of Sardinella longiceps (valenciennes) in the sultanate of Oman. Kuwait Bull. Mar. Sc., (10):201-20.

11- Bragagnolo, N. and Rodriguez-Amaya, D.B. (1993). Avaliação comparativa de três métodos para determinação de colesterol em gema de ovo. Arq Biol Tecnol., 6(2):237-251.

12-Hassan,T.M.; Shakhtoor, F.; Ahmad, A.A. and Al Mallah, M.A. (2011). Monthly changes in the composition of fish fattening from the shores of Libya. Libyan J. Agric. Sci.,16 (2): 3644. (in Arabic)

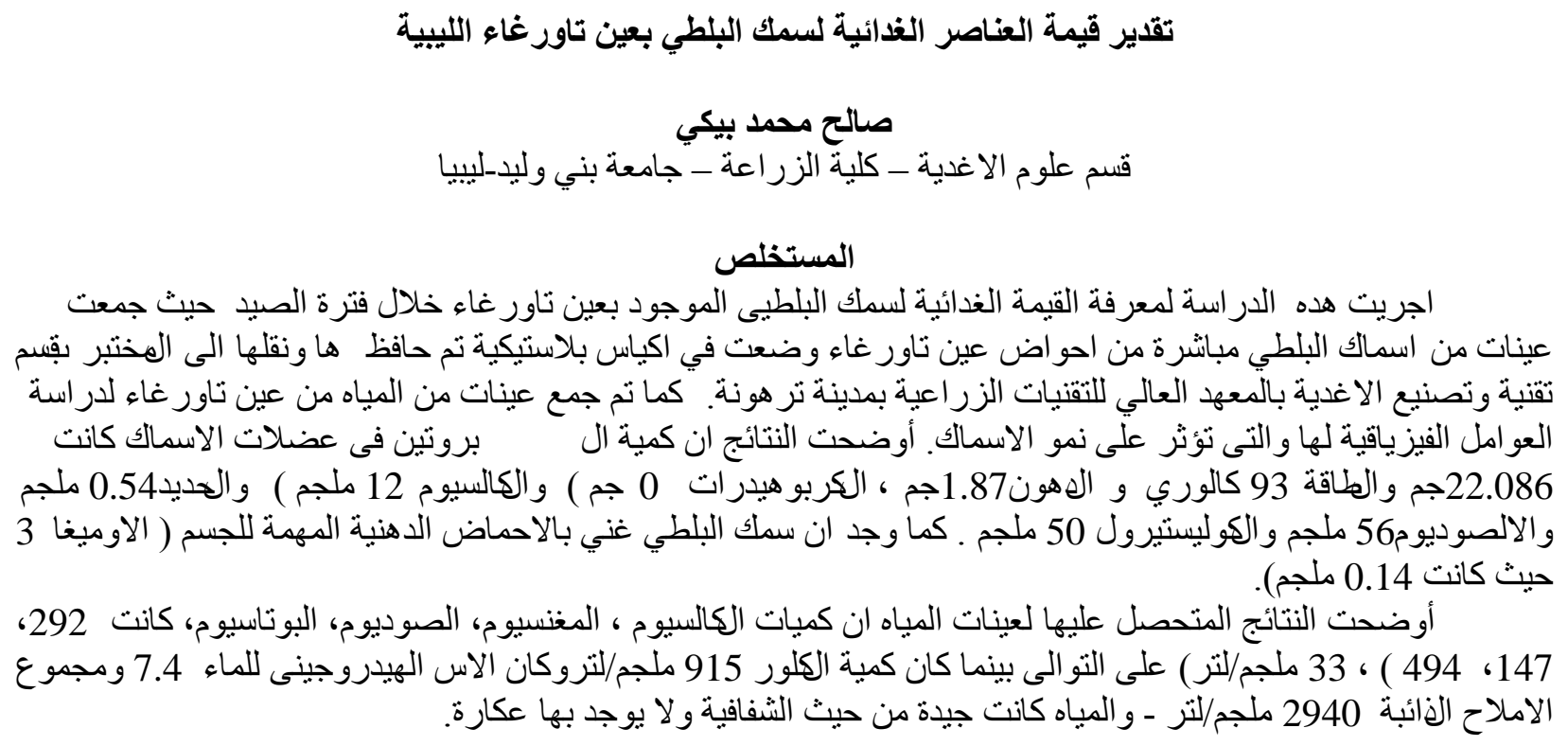

